\title{
FAKTOR-FAKTOR YANG MEMPENGARUHI KINERJA KADER JUMANTIK DALAM PEMBERANTASAN DBD DI PUSKESMAS KEDUNG BADAK KOTA BOGOR TAHUN 2019
}

\author{
Winda Meilina1, T. Abdul Madjid², Indira Chotimah ${ }^{3}$ \\ ${ }^{1}$ Konsentrasi Management Pelayanan Kesehatan, Program Studi Kesehatan Masyarakat, Fakultas Ilmu Kesehatan \\ Universitas Ibn Khaldun Bogor. Email : mlnawinda14@gmail.com \\ ${ }^{2}$ Program Studi Kesehatan Masyarakat, Fakultas Ilmu Kesehatan Universitas Ibn Khaldun Bogor. \\ Email : abd.madjid@uika-bogor.ac.id \\ ${ }^{3}$ Program Studi Kesehatan Masyarakat, Fakultas Ilmu Kesehatan Universitas Ibn Khaldun Bogor. \\ Email : indira@uika-bogor.ac.id
}

\begin{abstract}
Abstrak
Masalah yang terdapat di Indonesia adalah penyakit demam berdarah dengue (DBD) penyakit ini pertama kali terjadi di Surabaya dan Jakarta pada Tahun 1968 dengan jumlah kematian 24 orang. Kemudian jumlah kasus bertambah seiring dengan meluasnya daerah endemis DBD dimana tahun 2011 menyebar keseluruh Indonesia. Salah satu pencegahan DBD yaitu dengan menggerakkan kader juru pemantau jentik (jumantik). Kader jumantik adalah kelompok kerja kegiatan pemberantasan penyakit demam berdarah dengue di tingkat desa dalam wadah lembaga ketahanan masyarakat desa. Penelitian ini menggunakan desain cross sectional. Populasi dalam penelitian ini sebanyak 35 responden. Sampel dalam penelitian ini sebanyak 35 responden dengan teknik pengambilan sampel yaitu menggunakan sampling jenuh. Alat yang digunakan dalam penelitian ini kuesioner. Dan cara analisa data menggunakan perangkat lunak aplikasi statistik. Hasil penelitian berdasarkan analisa data didapatkan bahwa terdapat hubungan anatara pembelajaran ( $p$-value 0,005), kepemimpinan ( $p$-value 0,041), sumber daya ( $p$-value 0,027$)$ dan imbalan ( $p$-value 0,050$)$ terhadap kinerja kader jumantik dan tidak ada hubungan antara umur ( $p$-value 0,440$)$, pendidikan ( $p$-value 0,130$)$, lama kerja ( $p$-value 0,961$)$, motivasi ( $p$-value 0,1000$)$ dan sikap ( $p$-value 0,352 ) terhadap kinerja kader jumantik. Kesimpulan dalam penelitian ini ada hubungan antara pembelajaran, kepemimpinan, sumber daya, imbalan terhadap terhadap kinerja kader jumantik. Dan tidak ada hubungan antara umur, pendidikan, lama kerja, motivasi dan sikap. Saran yang dapat diberikan yaitu agar meningkatkan starategi dalam program pemberantasan sarang nyamuk meningkatkan koordinasi dan pertemuan rutin dengan kader jumantik.
\end{abstract}

Kata kunci : Kader Jumantik, Faktor Individu dan Faktor Sikap, Kepemimpinan, Imbalan.

\section{PENDAHULUAN}

Di Indonesia Penyakit Demam Berdarah Dengue (DBD) masih menjadi masalah kesehatan utama. Di Indonesia penyakit ini pertama kali dilaporkan terjadi di Surabaya dan Jakarta pada tahun 1968 dengan jumlah kematian sebanyak 24 orang. Kemudian jumlah kasus terus bertambah seiring dengan semakin meluasnya daerah endemis DBD dimana pada tahun 2011 penyakit ini telah menyebar ke seluruh provinsi di Indonesia (34 provinsi dan 400 Kabupaten/Kota). Total kasus DBD tahun 2016 sebanyak 204.171 (IR 78,85/100.000 
penduduk) dengan kematian sebanyak 1.598 (CFR 0,78\%). Kasus terbanyak ditemukan di Provinsi Jawa Barat disusul Jawa Timur dan Bali. (Renstra Kemenkes RI, 2015-2019).

Insidens Rate DBD Kota Bogor selama tahun 2016 yaitu sebesar 122,3 per 100.000 penduduk, meningkat dari tahun 2015 yaitu sebesar 105,4 per 100.000 penduduk. Kasus tertinggi terjadi di kecamatan Tanah Sareal sebanyak 307 kasus (26,28\%) dan Bogor Barat sebanyak 262 kasus (21,86\%). Hal ini berkaitan dengan tingginya tingkat kepadatan penduduk tentang kebersihan lingkungan, sehingga pengendalian vektor belum dapat dilakukan dengan baik.

Profil Puskesmas Kedung Badak (2018), Kasus Penyakit menular tahun 2018 yang ditangani oleh Puskesmas Kedung Badak adalah Kasus Demam Berdarah Dengue (DBD) sebanyak 94 kasus ditangani 100\%, Kasus DBD ini setiap tahun selalu ada di tiga kelurahan yaitu kelurahan Kedung Jaya, Kedung Waringin dan Kedung Badak, ini merupakan penyakit endemis, yang harus ada usaha dari masyarakat itu sendiri untuk berperilaku PHBS, dengan meningkatkan PSN, supaya tidak ada lagi DBD ini di samping dari petugas Surveilance dan Promkes untuk meningkatkan penyuluhan kepada masyarakat untuk merubah perilaku masyarakat kurang baik.

Apabila masyarakatnya mempunyai kesadaran yang tinggi terhadap kebersihan dan kesehatan lingkungan akan berdampak baik pada kesehatan lingkungan. Oleh sebab itu, penanganan yang tepat terhadap wawasan, kebiasaan, sikap, perilaku masyarakat akan pentingnya kebersihan dan kesehatan lingkungan sangat berkaitan dengan keberhasilan penanganan penyakit demam berdarah ini. (Sukowati, 2010)

\section{METODE}

Penelitian ini merupakan penelitian kuantitatif dengan desain studi cross sectional. Dimana penelitian ini yang dilakukan dengan mengambil waktu tertentu yang relatif pendek dan tempat tertentu, dilakukan sekali waktu pada saat yang bersamaan (Sujarweni, 2015). Penelitian ini dilakukan pada bulan januari tahun 2019 di Puskesmas Kedung badak pada petugas beralamat perumahan Kedungbadak kota Bogor. Dengan variabel bebas (variable independent) meliputi : umur, pendidikan terakhir, lama kerja, motivasi, sikap, pembelajaran/ pelatihan, sumberdaya/ fasilitas, kepemimpinan dan imbalan. Dan variabel terikat (variable dependent) meliputi : kinerja kader jumantik.

\section{HASIL}

Data yang diperoleh dianalisa malalui komputer dengan menggunakan program Statistical Package for Social Science (SPSS) versi 20. Berikut hasil pengelolaan data penelitian. Berdasarkan hasil analisis univariat berdasarkan umur kinerja kader jumantik diketahui sebagian besar usia 40-49 tahun (68,8\%) dan sedikit yang berumur 50-59 tahun $(31,4 \%)$.

Berdasarkan faktor individu lainya yaitu pendidikan diketahui responden > SMA $(51,4 \%)$, dan responden dengan pendidikan $\geq$ SMA $(48,6 \%)$. berdasarkan lama kerja diketahui lama kerja terlama 0-5 tahun adalah > 5 tahun $(57,1 \%)$. Berdasarkan Motivasi sebagian besar tidak ada yaitu (60\%). Berdasarkan faktor sikap, bahwa sebagian besar tidak baik sebanyak (54,3\%). Berdasarkan pembelajaran sebagia besar tidak adanya pembelajaran $(62,9 \%)$. Berdasarkan sumberdaya sebagian besar tidak adanya sumberdaya $(82,9 \%)$. 
Berdasarkan kepeminpinan sebagian besar tidak ada jiwa kepemimpinan sebanyak (51,4\%).

Dari hasil analisis bivariat (chi square) dalam tabel 1 - tabel 8 dapat diketahui bahwa variabel yang memiliki hubungan yang signifikan dengan Kinerja Kader Jumatik adalah pembelajaran ( $p$-value 0,005), sumberdaya ( $\mathrm{p}$-value 0,027), kepemimpinan ( $p$-value0.041). sedangkan variabel yang tidak berhubungan secara signifikan adalah umur ( $p$-value 0,440 ),variabel pendidikan ( $p$-value 130 ) lama kerja ( $\mathrm{p}$-value0,961), motivasi ( $\mathrm{p}$-value $0,1000)$ sikap (p-value 352).

Tabel 1. Hubungan Tingkat Kebisingan Terhadap keluhan gangguan pendengaran

Tabel 1 Hubungan umur dengan Kinerja Jumantik

\begin{tabular}{|c|c|c|c|c|c|c|c|c|}
\hline \multirow{3}{*}{ Umur } & \multicolumn{3}{|c|}{ Kinerja Jumantik } & \multirow{2}{*}{\multicolumn{3}{|c|}{ Total }} & \multirow{3}{*}{$\begin{array}{l}\mathrm{P} \\
\text { Value }\end{array}$} & \multirow{3}{*}{$\begin{array}{l}\text { OR } \\
(95 \% \mathrm{Cl})\end{array}$} \\
\hline & \multicolumn{2}{|c|}{ Baik } & Kurang & & & & & \\
\hline & $\mathrm{N}$ & $\%$ & $\mathrm{~N}$ & $\%$ & $\mathrm{~N}$ & $\%$ & & \\
\hline 40-49 tahun & 13 & 13,7 & 11 & 10,3 & 24 & 100 & \multirow[t]{2}{*}{0,440} & \multirow[t]{2}{*}{$0,675(0,156-2930)$} \\
\hline 50-59 tahun & 7 & 6,3 & 4 & 4,7 & 11 & 100 & & \\
\hline Total & 20 & 20 & 15 & 15 & 35 & 100 & & \\
\hline
\end{tabular}

Tabel 2. Hubungan Pendidikan Dengan Kinerja Jumantik

\begin{tabular}{|c|c|c|c|c|c|c|c|c|}
\hline \multirow{3}{*}{ Pendidikan } & \multicolumn{3}{|c|}{ Kinerja Jumantik } & \multirow{2}{*}{\multicolumn{3}{|c|}{ Total }} & \multirow{3}{*}{$\begin{array}{l}\mathrm{P} \\
\text { Value }\end{array}$} & \multirow[b]{2}{*}{$\begin{array}{l}\text { OR } \\
(95 \% \mathrm{Cl})\end{array}$} \\
\hline & \multicolumn{2}{|c|}{ Baik } & $\begin{array}{l}\text { Kurang } \\
\text { Baik }\end{array}$ & & & & & \\
\hline & $\mathrm{N}$ & $\%$ & $\mathrm{~N}$ & $\%$ & $\mathrm{~N}$ & $\%$ & & \\
\hline$>$ SMA & 13 & 10 & 5 & 7,7 & 18 & 100 & 0,130 & (0904- \\
\hline$<$ SMA & 7 & 9,7 & 10 & 7,3 & 17 & 100 & & $15,620)$ \\
\hline Total & 20 & 20 & 15 & 15 & 35 & 100 & & \\
\hline
\end{tabular}

Tabel 3. Hubungan Lama Kerja Dengan Kinerja Jumantik

\begin{tabular}{|c|c|c|c|c|c|c|c|c|}
\hline \multirow{3}{*}{$\begin{array}{l}\text { Lama } \\
\text { Kerja }\end{array}$} & \multicolumn{4}{|c|}{ Kinerja Jumantik } & \multirow{2}{*}{\multicolumn{2}{|c|}{ Total }} & \multirow{3}{*}{$\begin{array}{l}\mathrm{P} \\
\text { Value }\end{array}$} & \multirow{3}{*}{$\begin{array}{l}\text { OR } \\
(95 \% \mathrm{Cl})\end{array}$} \\
\hline & \multicolumn{2}{|l|}{ Baik } & \multicolumn{2}{|c|}{ Kurang Baik } & & & & \\
\hline & $\mathrm{N}$ & $\%$ & $\mathrm{~N}$ & $\%$ & $\mathrm{~N}$ & $\%$ & & \\
\hline $0-5$ tahun & 12 & 11,4 & 8 & 8,6 & 20 & 100 & 0,961 & 0,1313 \\
\hline $6-10$ tahun & 8 & 8,6 & 7 & 6,4 & 15 & 100 & & $5,076)$ \\
\hline Total & 20 & 20 & 15 & 15 & 35 & 100 & & \\
\hline
\end{tabular}

Tabel 4. Hubungan Motivasi Kerja Dengan Kinerja Jumatik

\begin{tabular}{|c|c|c|c|c|c|c|c|c|}
\hline \multirow{3}{*}{ Motivasi } & \multicolumn{4}{|c|}{ Kinerja Jumantik } & & & \multirow{3}{*}{$\begin{array}{l}\mathrm{P} \\
\text { Value }\end{array}$} & \multirow{3}{*}{$\begin{array}{l}\text { OR } \\
(95 \% \mathrm{Cl})\end{array}$} \\
\hline & \multicolumn{2}{|c|}{ Baik } & \multicolumn{2}{|c|}{ Kurang Baik } & \multicolumn{2}{|c|}{ Total } & & \\
\hline & $\mathrm{N}$ & $\%$ & $\mathrm{~N}$ & $\%$ & $\mathrm{~N}$ & $\%$ & & \\
\hline Ada & 8 & 8 & 6 & 6 & 15 & 100 & 0,1000 & $(0,255$ \\
\hline Tidak ada & 12 & 12 & 9 & 9 & 20 & 100 & & 3922) \\
\hline Total & 20 & 20 & 15 & 15 & 35 & 100 & & \\
\hline
\end{tabular}


Tabel 5 Hubungan Sikap dengan Kinerja Jumatik

\begin{tabular}{|c|c|c|c|c|c|c|c|c|}
\hline \multirow[t]{3}{*}{ Sikap } & \multicolumn{3}{|c|}{ Kinerja Jumantik } & \multirow{2}{*}{\multicolumn{3}{|c|}{ Total }} & \multirow{3}{*}{$\begin{array}{l}\mathrm{P} \\
\text { Value }\end{array}$} & \multirow{3}{*}{$\begin{array}{l}\text { OR } \\
(95 \% \mathrm{Cl})\end{array}$} \\
\hline & \multicolumn{2}{|c|}{ Baik } & Kurang & & & & & \\
\hline & $\mathrm{N}$ & $\%$ & $\mathrm{~N}$ & $\%$ & $\mathrm{~N}$ & $\%$ & & \\
\hline Baik & 11 & 9,1 & 5 & 6,9 & 16 & 100 & 0,352 & $2,444(0,610-9801)$ \\
\hline Kurang Baik & 9 & 10,9 & 10 & 8,1 & 19 & 100 & & \\
\hline Total & 20 & 20 & 15 & 15 & 35 & 100 & & \\
\hline
\end{tabular}

Tabel 6 Hubunagan Pembelajaran dengan Kinerja Jumantik

\begin{tabular}{|c|c|c|c|c|c|c|c|c|}
\hline \multirow{3}{*}{ Pembelajaran } & \multicolumn{3}{|c|}{ Kinerja Jumantik } & & & & \multirow{3}{*}{$\begin{array}{l}\mathrm{P} \\
\text { Value }\end{array}$} & \multirow{3}{*}{$\begin{array}{l}\text { OR } \\
(95 \% \mathrm{Cl})\end{array}$} \\
\hline & \multicolumn{2}{|c|}{ Baik } & \multirow{2}{*}{$\begin{array}{l}\text { Kurang } \\
\text { Baik } \\
\mathrm{N} \\
\end{array}$} & \multicolumn{3}{|c|}{ Total } & & \\
\hline & $\mathrm{N}$ & $\%$ & & $\%$ & $\mathrm{~N}$ & $\%$ & & \\
\hline Ada & 3 & 7,4 & 10 & 5,6 & 13 & 100 & \multirow[t]{2}{*}{0,005} & \multirow[t]{2}{*}{$0,88(0,14-451)$} \\
\hline Tidak Ada & 17 & 12,6 & 5 & 9,4 & 22 & 100 & & \\
\hline Total & 20 & 20 & 15 & 15 & 35 & 100 & & \\
\hline
\end{tabular}

Tabel 7. Hubungan Sumberdaya Dengan Kinerja Jumantik

\begin{tabular}{|l|c|c|c|c|l|l|l|l|}
\hline \multirow{2}{*}{$\begin{array}{l}\text { Sumber } \\
\text { daya }\end{array}$} & \multicolumn{4}{|l|}{ Kinerja Jumantik } & \multicolumn{2}{l|}{ Total } & \multirow{2}{*}{$\begin{array}{l}\text { P } \\
\text { Value }\end{array}$} & $\begin{array}{l}\text { OR } \\
(95 \% \mathrm{Cl})\end{array}$ \\
\cline { 2 - 9 } & Baik & $\mathrm{N}$ & $\%$ & $\mathrm{~N}$ & $\%$ & $\mathrm{~N}$ & $\%$ & Value \\
\hline Ada & 6 & 11,4 & 0 & 2,6 & 6 & 100 & 0,027 & $\begin{array}{l}2071(1421- \\
3019)\end{array}$ \\
\hline Tidak Ada & 14 & 8,6 & 15 & 12,4 & 29 & 100 & & \\
\hline Total & 20 & 20 & 15 & 15 & 35 & 100 & & \\
\hline
\end{tabular}

Tabel 8 Hubungan Imbalan dengan Kinerja Jumatik

\begin{tabular}{|c|c|c|c|c|c|c|c|c|}
\hline \multirow{3}{*}{ Imbalan } & \multicolumn{4}{|c|}{ Kinerja Jumantik } & & & \multirow{3}{*}{$\begin{array}{l}\mathrm{P} \\
\text { Value }\end{array}$} & \multirow{3}{*}{$\begin{array}{l}\text { OR } \\
(95 \% \mathrm{Cl})\end{array}$} \\
\hline & \multicolumn{2}{|c|}{ Baik } & \multicolumn{2}{|c|}{ Kurang Baik } & \multicolumn{2}{|c|}{ Total } & & \\
\hline & $\mathrm{N}$ & $\%$ & $\mathrm{~N}$ & $\%$ & $\mathrm{~N}$ & $\%$ & & \\
\hline Ada & 2 & 4,6 & 6 & 6 & 8 & 100 & 0,050 & $(0,028-$ \\
\hline Tidak ada & 18 & 15,4 & 9 & 9 & 27 & 100 & & $0,997)$ \\
\hline Total & 20 & 20 & 15 & 15 & 35 & 100 & & \\
\hline
\end{tabular}

\section{PEMBAHASAN}

Berdasarkan tabel 1, diperoleh hasil bahwa tidak ada hubungan yang signifikan antara umur dengan kinerja Jumantik Responden. Hasil penelitian ini sejalan dengan Yusvita (2017) Analisis Partisipasi Kader Jumantik dalam Upaya Penanggulangan DBD di Wilayah Kerja Puskesmas Indralaya dikatakan bahwa tidak adanya hubungan antara umur dengan kinerja jumantik di wilayah kerja Puskesmas Indralaya dengan nilai $p$-value 0,088.

Berdasarkan tabel 2, diperoleh hasil bahwa tidak ada hubungan yang signifikan antara pendidikan dengan kineja jumantik. Hasil penelitian ini tidak sejalan dengan penelitian yang dilakukan oleh Prambudi (2009) di Desa Ketitang Kecamatan Negosari Kabupaten Boyolali menunjukan bahwa Faktor yang mempengaruhi Partisipasi Kader Jumantik dalam Pemberantasan DBD mengatakan adanya hubungan antara Pendidikan dengan kinerja 
jumantik DBD.

Berdasarkan tabel 3, diperoleh hasil bahwa tidak ada hubungan yang signifikan antara lama kerja dengan kinerja jumantik. Hasil penelitian sejalan dengan hasil penelitian Pangestika (2017) Faktor-faktor yang Mempengaruhi Perilaku Jumantik dalam Sistem Kewaspadaan Dini DBB di Kelurahan Sendang Mulia dikatakan bahwa tidak adanya hubungan lama kerja dengan kinerja jumantik dengan nilai $p$-value 0,450 .

Berdasarkan tabel 4, diperoleh hasil bahwa tidak ada hubungan yang signifikan antara motivasi dengan kinerja jumantik. Hasil ini sejalan dengan penelitian yang dilakukan oleh Wiwik Wulandari (2015) Hubungan Motivasi Kader Pemberantasan Sarang Nyamuk dengan Upaya Pencegahan Demam Berdarah (DBD) di Wilayah Kerja Puskesmas Gemolong dikatakan bahwa tidak adanya hubungan antara motivasi kader PSN dalam upaya pencegahan DBD di Puskesmas Gemolong dengan nila $p$-value 0,613.

Berdasarkan tabel 5, diperoleh hasil bahwa tidak ada hubungan yang signifikan antara sikap dengan kinerja jumantik. Hasil penelitian sejalan dengan penelitian Muhammad Sadat Harahap (2017) Karakteristik Kader Kesehatan dan Perilaku Menggerakan Masyarakat dalam Penanggulangan DBD dikatakan bahwa tidak adanya hubungan antara sikap dengan kinerja kader dengan nilai $p$-value 0,482 .

Berdasarkan tabel 6, diperoleh hasil bahwa tidak ada hubungan yang signifikan antara pembelajaran dengan kinerja jumantik. Hasil penelitian ini sejalan dengan Aprinianis (2012) Faktor-faktor yang Berhubungan dengan Kinerja Jumantik di Wilayah kerja Puskesmas Jurang Manggu dan Pusekesmas Pondok Aren di Kota Tangerang Selatan Tahun 2012 dikatakan tidak adanya hubungan antara pembelajaran dengan kinerja jumantik di wilayah kerja puskesmas jurang mangu dan puskesmas pondok aren di Kota Tangerang Selatan Tahun 2012. Dengan nilai p-value 0,004 .

Berdasarkan tabel 7, diperoleh hasil bahwa ada hubungan yang signifikan antara sumber daya dengan kinerja jumantik. Hasil penelitian ini tidak sejalan dengan Pambudi (2009) Faktor-faktor yang mempengaruhi partisipasi Kader Jumantik dalam Pemberantasan DBD di Desa Ketitang Kecamatan Nogosari Kabupaten Boyolali dikatakan tidak ada hubungan antara sumber daya dengan kinerja jumantik dengan nilai $p$-value 0,654.

Berdasarkan tabel 8, diperoleh hasil bahwa ada hubungan yang signifikan antara imbalan dengan kinerja jumantik. Hasil penelitian ini tidak sejalan dengan Ari (2009) dimana tidak adanya hubungan antara imbalan dengan kinerja jumantik di kelurahan cilandak timur dengan nilai $p$-value 0,1000 dikatakan bahwa hal tersebut dapat terjadi karena insentif yang diberikan tidak mencukupi dan tidak teratur sehingga merasa tidak dihargai dan dapat menurunkan kinerja.

\section{KESIMPULAN}

Berdasarkan hasil penelitian di Puskesmas Kedung Badak Tahun 2019, tentang Faktor-faktor Yang Berhubungan Dengan Kinerja Kader Jumantik Demam Berdarah (DBD) Tahun 2019 maka peneliti dapat menyimpulkan :

1. Berdasarkan karakteristik responden, umur responden mayoritas berumur 40-49 tahun yaitu 68,6\%.

2. Berdasarkan karakteristik pendidikan responden lebih banyak responden dengan 
pendidikan diatas SMA 51,4\%.

3. Berdasarkan karakteristik lama kerja responden, lebih mayoritas di lama kerja 0-5 tahun yaitu 57,1\%.

4. Berdasarkan karakteristik motivasi responden mayoritas tidak memiliki motivasi yaitu $60 \%$.

5. Berdasarkan karakteristik sikap responden lebih mayoritas memiliki sikap yang tidak baik yaitu $54,3 \%$, dibandingkan dengan sikap yang baik 45,7\%.

6. Berdasarkan karakteristik pembelajaran responden, pembelajaran mayoritas tidak adanya pembelajaran $62,9 \%$.

7. Berdasarkan karakteristik sumber daya mayoritas tidak memiliki sumber daya yaitu $82,9 \%$.

8. Berdasarkan karakteristik kepemimpinan mayoritas

\section{DAFTAR PUSTAKA}

Ari, Luthfiana. (2009). Kinerja Jumantik Kelurahan Cilandak Timur Tahun 2009. Skripsi: Program Sarjana Fakultas Kesehatan Masyarakat, Universitas Indonesia

Chotimah, I., Oktaviani, S., \& Madjid, A. (2018). Evaluasi Program Tb Paru Di Puskesmas Belong Kota Bogor Tahun 2018. PROMOTOR, 1(2), 87-95.

Chotimah, I., Anggraini, D. (2018). Pemberdayaan Masyarakat Melalui Peningkatan Kualitas Pendidikan, Ekonomi, Kesehatan Dan Lingkungan. ABDIDOS 2 (1), 62-72.

Chotimah, I. (2017). Gambaran Perilaku Merokok Mahasiswa Universitas Ibn Khaldun Bogor 2013. HEARTY 5 (1).

Dalimunthe. (2009). Faktor-Faktor Yang Mempengaruhi Partisipasi Masyarakat Dalam

Pencegahan Program Malaria Di Kecamatan Saibu Kabupaten Mandailing Natal. Tesis:

FKM, Universitas Sumatera Utara

Departemen Kesehatan Republik Indonesia. (2011). Direktorat Jendral, P2PL. Membina

Gerakan Pemberantasan Sarang Nyamuk Demam Berdarah Dengue (Pemberantas Sarang Nyamuk DBD). Jakarta

Departemen Kesehatan Republik Indonesia. (2014). Dierktorat Jendral P2B2. Modul Pengendalian Demam Berdarah Dengue. Kementrian Kesehatan Republik Indonesia. Jakarta

Departemen Kesehatan Republik Indonesia. (2011). Dierktorat Jendral Pengendalian Penyakit dan Penyehatan Lingkungan. Penyakit Pemberantasan sarang Nyamuk Demam Berdarah Dengue (PSN DBD) oleh Juru Pemantau Jentik (Jumantik) tidak memiliki jiwa kepemimpinan yaitu $51,4 \%$.

Departemen Republik Indonesia (2009). Profil Kesehatan Indonesia. Jakarta: Departemen Republik Indonesia, Jakarta

Desi Ni Putu Ary Sandhi (2013), Pengaruh Faktor Motivasi Terhadap Kinerja Juru Pemantau Jentik Dalam Pelaksanaan Pemberantasan Sarang Nyamuk Di Kecamatan Denpasar Selatan Tahun 2013. Jurnal : Ilmu Kesehatan Masyarakat Fakultas Kedokteran, Universitas Udayana

Dewi. (2015). Faktor-Faktor Yang Berhubungan dengan Praktik Pemberantasan Sarang Nyamuk Demam Berdarah Dengue (PSN DBD) Keluarga Di Kelurahan Mulyaharjo 
Kecamatan Jepara Kabupaten Jepara. Jurnal: Universitas Negeri Semarang

Dwi Novi Arini. (2014). Hubungan Antara Karakteristik Juru Pemantau Jentik (Jumantik)Terhadap Status Angka Bebas Jentik (ABJ) Di Kelurahan Wonotingal Wilayah Kerja Puskesmas Kagok Tahun 2014. Jurnal: FKM, Universitas Dian Nuswontoro. Semarang

Dinas Kesehatan Kota Bogor. (2015-2016). Data Profil Kesehatan Tahunan Kota Bogor. Bogor: Dinkes, Kota Bogor

Fitrini. (2009). Kinerja Jumantik Dalam Pemberantasan Penyakit Demam Berdarah Dengue (P2DB) Di Kelurahan Pasar Minggu Kecamatan Pasar Minggu Jakarta Selatan. Skripsi: Program Paascasarjana Fakultas Kesehatan Masyarakat, Universitas Indonesia

Febrianti, Ika Rusma dan AR. (2015). Hubungan Antara Pengetahuan, Sikap dan Peran Tenaga

Kesehatan Dengan Perilaku Kader Sebagai Petugas Jumantik di Puskesmas Tanjung

Sekayam Kabupaten Sanggau. Jurnal: Fakultas Kesehatan Masyarakat, Jakarta

Gibson. (2009). Organisasi Perilaku, Struktur, Proses, Jilid 1. Penerbit Erlangga, Jakarta

Guzman, M. G., Alvarez, M \& Halstead,

S.B. (2013). Secondary Infection as a risk factor for dengue hemorrhagic fever/dengue shock syndrome : an historical perspective and roly antibody dependen enhancement of Inspection. Archhives Of Virology, 158(7), 1445-1459. doi: 10.1007/s00705-013-1645-

3. Diakses pada tanggal 28 september 2019

Hafshah. (2012). Faktor-Faktor Yang Mempengaruhi Partisipasi Kader Jumantik Dalam Upaya

Pemberantasan Sarang Nyamuk Di Desa Wirogunan Kecamatan Kertasura Kabupaten Sukoharjo.

Jurnal: Program Studi DIII, Fakultas Kesehatan, Universitas MH.Thamrin Hamali, Arif Yusuf. (2018). Pemahaman Manajemen Sumber Daya Manusia. Yogyakarta Buku seru.

Hartono, D. (2014). Pengaruh Sarana Prasarana Dan Lingkungan Kerja Terhadap Kinerja Pegawai Dinas Pendidikan Kota Banjarbaru. Jurnal: FKM, Jakarta

Hastono : Sutanto Priyo. (2009). Analisis Data Kesehatan. Depok : Fakultas Kesehatan Masyarakat. Universitas Indonesia

Hikmwati, Fenti. (2017). Metodologi Penelitian. Jakarta : Rajagrafindo Persada, Jakarta

Ife, Jim et all. (2008). Alternatif Pengembangan Masyarakat Di Era Globalisasi, Yogyakarta:

Pustaka Belajar

Inatulit. (2016). Faktor-Faktor Yang Berhubungan Dengan Peran Kader Jumantik Dalam

Upaya Pencegahan Demam Berdarah Dengue Di Wilayah Kerja Puskesmas Ambarawa

Tahun 2016. Jurnal: Fakultas Kesehatan

Kasmir. (2016). Manajemen Sumber Daya Manusia (Teori dan Praktik). Jakarta: BPFE, Jakarta Kementerian Kesehatan Republik Indonesia. (2014). Modul Pengendalian Demam Berdarah Dengue. Jakarta

Kementerian Kesehatan Republik Indonesia. (2012). Petunjuk Teknis Penggerakkan Pemberantasan Sarang Nyamuk DBD. Direktorat Jendral Pengendalian Penyakit dan Penyehatan Lingkungan Kemenkes RI Indonesia

Kumara. (2016). Pengaruh Pelatihan Terhadap Kinerja Karyawan dengan Mediasi Kepemimpinan Pada Hotel Satriya Cottages Kuta Bali. Jurnal: FKM, Jakarta

Kusyogo, Cahyo. (2017). Faktor-Faktor Yang Mempengaruhi Jumantik Dalam Sistem 
Kewaspadaan Dini Demam Berdarah Dengue Di Kelurahan Sendang Mulyo. Jurnal: FKM. Universitas Dipenogoro, Semarang

Lestari EP, Madjid A, Nasution A. Faktor-Faktor yang Mempengaruhi Layanan Promosi Kesehatan pada Pasien Tuberkulosis Paru di Ruang Eboni Lantai 3 RS PMI Bogor Tahun 2017. Mhs Kesehat Masy. 2018;1(1):45-52.

Luthaefa Hadaana. (2016). Faktor-faktor Yang Mempengaruhi Peran Kader Jumantik Dalam Upaya Peningkatan Angka Bebas Jentik (ABJ) Di Wilayah Kerja Puskesmas Rowosari Tahun 2016. Skripsi: Jurusan Ilmu Kesehatan Masyarakat, Universitas Negeri Semarang Maulina L, Madjid TA, Chotimah I. Hubungan Mutu Pelayanan Kesehatan Dengan Kepuasan Pasien Peserta BPJS di Unit Rawat Inap Puskesmas Cibungbulang Kabupaten Bogor Tahun 2018. PROMOTOR. 2019;2(2):130-6.

Mangkunegara. (2013). Manajemen Sumber Daya Manusia. Perusahan penerbit: ROSDA, Bandung

Mubarak. (2010). Promosi Kesehatan Pengantar Belajar Mengajar Dalam Pendidikan. Yogyakarta: Graha Ilmu, Yogyakarta

Muhammad Sadat Harahap. (2017). Karakteristik Kader Kesehatan Dan Perilaku Menggerakkan Masyarakat Dalam Penanggulangan Demam Berdarah Tahun 2017. Jurnal: Fakultas Ilmu Sosial dan Ilmu Politik, Universitas Sumatera Utara

Muliawati, Emy. (2016). Hubungan Pendidikan Dan Pelatihan Jumantik Dengan Keberhasilan Program PSN Di Kelurahan Tanah Kalikedinding Kota Surabaya. Jurnal: Keperawatan Muhamadiyah, Surabaya

Mustikawati, (2013). Etika Penelitian. Jakarta : Halaman 1-5 https://imee351.weblog.esaunggul.ac.id/wp.content/uploads/sites/335/201

3/04/metodelogi-penelitian- pertemuan-9.doc diakes pada tanggal 2 Juni 2019

Montung. (2012). Hubungan Perilaku Masyarakat Dalam Pencegahan Demam Berdarah Di Wilayah Kerja Puskesmas Kolongan Minahasa Utara. Jurnal: Fakultas Kesehatan

Mumpuni, dr. Yekti. (2015). Cekal (Cegah dan Tangkal) sampai tuntas Demam Berdarah Dengue (DBD). Yogyakarta. Andi Offset

Mustikawati, Intan Silvina. (2013). Etika Penelitian. Depok : Pusat Kajian Ekonomi FKM. Universitas Indonesia

Ngurah Ketut. (2010). Hubungan Motivasi Petugas Terhadap Timeliness Surveilans Diare Di Kabupaten Kebumen Bulan Januari-Juni Tahun 2010. Tesis: Fakultas Kesehatan Masyarakat Program Studi Epidemiologi, Universitas Indonesia

Novera Aretha Hutapea. (2013). Gambaran Kinerja Kader Jumantik Dalam Pemberantasan Sarang Nyamuk DBD Di Kecamatan Padang Hulu Kota Tebing Tinggi Tahun 2013. Jurnal: Program Sarjana, FKM USU

Nursalam. (2014). Manajemen Keperawatan Aplikasi Praktik Keperawatan Profesional. Salemba Medika, Jakarta

Notoatmodjo Soekidjo. (2009). Promosi Kesehatan dan Ilmu Perilaku. Rineka Cipta PT. Jakarta Nurul Rezania. (2015). Hubungan Karakteristik Individu Dengan Praktik Kader Jumantik Dalam PSN DBD Di Kelurahan Sampangan Semarang. Jurnal: Jurusan Ilmu Kesehatan Masyarakat, Universitas Negeri Semarang

Pambudi. (2009). Faktor-faktor yang Mempengaruhi Partisipasi Kader Jumantik dalam 
Pemberantasan DBD di Desa Ketitang Kecamatan Nogosari Kabupaten Boyolali Tahun 2009. Skripsi: Fakultas Kesehatan Masyarakat, Universitas Muhamadiyah Surakarta

Pangestika Tegar Lyana. (2017). Faktor- Faktor Yang Mempengaruhi Perilaku Jumantik Dalam

Sistem Kewaspadaan Dini Demam Berdarah Dengue Di Kelurahan Sendangmulyo Tahun

2017. Jurnal Fakultas Kesehatan Masyarakat, Universitas Diponegoro. Semarang

Peraturan Menteri Kesehatan Republik Indonesia (2014) Nomor 75 Tentang Pusat Kesehatan Masyarakat. Jakarta

Profil Kesehatan. (2015-2016). Profil Tahunan 2015-2016. Dinas Kesehatan Kota Bogor, Jawa Barat

Profil Kesehatan. (2016). Profil Tahun 2016. Dinas Kesehatan Provinsi Jawa Barat. https//www.depkes.go.id.

Profil Kesehatan Tahun 2016 diakses pada tanggal 15 April 2019

Profil Puskesmas Kedung Badak. (2018). Profil Tahunan Puskesmas Kedung Badak Tahun 2018. Kota Bogor, Jawa Barat

Rencana Strategis Kementrian Kesehatan Republik Indonesia Tahun 2015- 2019 Nomor HK.02.02/Menkes/2015 diakses pada tanggal 6 April 2019

Rahayu Yusvita, (2017). Analisis Partisipasi Kader Jumantik Dalam Upaya Penangggulangan Demam Berdarah Dengue (DBD) Di Wilayah Kerja Puskesmas Indralaya Tahun 2017. Jurnal: Fakultas Kesehatan Masyarakat, Universitas Sriwijaya

R I Bay Aprinianis. (2012). Faktor-faktor yang Berhubungan dengan Kinerja Jumantik di Wilayah Kerja Puskesmas Jurang Manggu dan Puskesmas Pondok Aren Kota Tangerang Selatan Tahun 2012. Skripsi: Fakultas Ilmu Kesehatan Masyarakat. Universitas Indonesia Rivai. (2010). Kepemimpinan dan Perilaku Organisasi. Penerbit: Raja Grafindo Persada, Jakarta

Riza, Fauzia H. (2012). Faktor-Faktor Yang Mempengaruhi Partisipasi Kader Jumantik Dalam Upaya Pemberantasan Sarang Nyamuk Di Desa Wirogunan Kecamatan Kertasura Kabupaten Sukoharjo. Skripsi: Program Studi Kesehatan Masyarakat Fakultas Ilmu Kesehatan, Universitas Muhamadiyah Surakarta

Rusli. (2009). Kinerja Jumantik Dalam Pemberantasan Demam Berdarah Dengue (P2BD) Di Kelurahan Pasar Minggu Kecamatan Paasar Minggu Jakarta Selatan. Skripsi: Program Pasca Sarjana Fakultas Kesehatan Masyarakat, Universitas Indonesia

Rosdiana. (2010). Hubungan Antara Pelaksanaan Pencegahan Sarang Nyamuk DBD. Jornal: Fakultas Kesehatan Masyrakat. Jakarta

Sarlito, dan Surwono. (2009). Pengantar Psikologi Umum. Jakarta: PT Raja Grafindo Persada, Jakarta

Sastrohadisuwiryo, B. Siswant. (2002). Manajemen Tenaga Kerja Indonesia. Bumi Aksara, Jakarta

Sutrischastini, A. (2015). Pengaruh Motivasi Kerja Terhadap Kinerja Pegawai Kantor Sekretariat Daerah Kabupaten Gunung Kidul. Jurnal: FKM, Yogyakarta

Sedarmayanti, dkk. (2012). Metedologi Penelitian. Bandung: CV. Mondar Maju, Bandung Sitorus, Andika Debora M. (2012). Gambaran Faktor-Faktor Yang Berhubungan Dengan Kinerja Pegawai Instalasi Laboratorium Klinik RSUP Fatmawati Tahun 2012. Depok: Universitas Indonesia 
Suarli, S dan Bachtiar. (2009). Manajemen Keperawatan dengan Pendekatan Praktik. Jakarta: Erlangga

Sudarmanto. (2009). Kinerja Dengan Dan Pengembangan Kompetensi SDM. Pustaka Belajar, Yogyakarta

Suharsaputra, Uhar. (2014). Metode Penelitian Kualitatif, Kuantitatif dan Tindakan, Refika Aditama. Bandung Sukowati, Soepratman. (2010). Masalah Vektor Demam Berdarah Dengue (DBD) dan Pengendaliannya di Indonesia, Buletin Jendela Epidemiologi, Volume 2, Agustus 2010. Jakarta

Supomo, R (2018). Pengantar Manajemen. Bandung : Yrama Widya. Bandung Sujarweni V Wiratma (2015). Statistik Untuk Kesehatan. Yogyakarta : Gava Media.

Uno, Hamzah. (2015). Teori Motivasi dan Pengukurannya. Jakarta: Bumi Aksara

Wibowo. (2011). Manajemen Kinerja. Rajawali Pers, Jakarta

Widiastuti. (2010). Hubungan Partisipasi Kader Dengan Kinerja Jumantik Dalam Pemberantasan Demam Berdarah Di Puskesmas Kertasura. Skripsi: Fakultas Kesehatan. Universitas Muhamadiyah Surakarta Widoyono, (2009). Penyakit Tropis Epidemiologi, Penularan, Pencegahan dan Pemberantasan. Erlangga, Semarang

Widyanti IT. (2009). Faktor-faktor Yang Mempengaruhi Tindakan Masyarakat Dalam Upaya Pencegahan Penyakit Demam Berdarah Dengue (DBD) Desa Makam Haji Wilayah Kerja Puskesmas II Kartasura Tahun 2009. Skripsi Fakultas Kedokteran Universitas Muhamadiyah. Surakarta Wawan, Dewi. (2010). Teori Dan Pengukuran Pengetahuan, Sikap Dan Perilaku Manusia. Yogyakarta: Nuha Medika

WHO 2019, Dengue And Savere Dengue, From Health Organization : https://www.who.int/news-room/factsheets/detail/dengue-and-severe-dengue diakses pada tanggal 15 September 2019

Wiwik Wulandari. (2015). Hubugan Motivasi Kader Pemberantasan Sarang Nyamuk (PSN) Dengan Upaya Pencegahan Demam Berdarah Dengue (DBD) Di Wilayah Kerja Puskesmas Gemolong Tahun 2015. Jurnal: Program Studi S1 Keperawatan, STKes Kusuma Husada Surakarta Wiwit Wijayanti. (2016). Faktor-Faktor yang berhubungan dengan Partisipasi Kader Dalam Pencegahan Demam Berdarah Dengue (DBD) Di Cikarang Kota Bekasi. Jurnal: Fakultas Kesehatan, Universitas MH Thamrin. Jakarta Timur

Yulianti NS. (2009). Pengaruh Keaktifan Juru Pemantau Jentik (Jumantik) Terhadap Angka Bebas Jentik (ABJ) Dan Kejadian Demam Berdarah Dengue (DBD) (Studi Pada Pelaksanaan “Gerakan Jumat Berseri+PSN 60 menit” Di Kota Mojokerto. Tesis: Airlangga University Library. Surabaya

Yuniar, Mia. (2012). Pengaruh Health Promotion Model Terhadap Peningkatan Pengetahuan dan Motivasi Kader Posyandu Di Kelurahan Kober Kecamatan Purwokerto Barat. Skripsi: Jurusan Keperawatan Fakultas Kedokteran dan Ilmu Kesehatan, Universitas Jendral Soedirman. Purwokerto 